\title{
Chicken Manure: An Alternative in Increasing Production of Sweet Potato (Ipomoea batatas)
}

\author{
Carla Coelho Ferreira ${ }^{1}$, Pamela Karoline Correia Brunner ${ }^{2}$, Ana Cecília Nina Lobato ${ }^{1}$, \\ Tassia Michelli Nogueira Negreiros ${ }^{1}$, Daniel Oscar Pereira Soares ${ }^{1} \&$ Albejamere Pereira de Castro ${ }^{1}$ \\ ${ }^{1}$ Graduate Program in Tropical Agronomy, Federal University of Amazonas, Manaus, Brazil \\ ${ }^{2}$ Faculty of Agricultural Sciences, Federal University of Amazonas, Manaus, Brazil \\ Correspondence: Carla Coelho Ferreira, Graduate Program in Tropical Agronomy, Federal University of \\ Amazonas, Manaus, Brazil. Tel: 55-92-99603-7995. E-mail: carlacoelhofigueiredo@gmail.com
}

Received: July 12, 2019 Accepted: August 16, $2020 \quad$ Online Published: September 15, 2020

doi:10.5539/jas.v12n10p141 URL: https://doi.org/10.5539/jas.v12n10p141

\begin{abstract}
Chicken manure is accessible to family farmers, is produced in large volumes, and has a low cost. Therefore, it can be an alternative to increase the productivity of sweet potatoes (Ipomoea batatas), which is a culture of socioeconomic importance. The objective of the study was to evaluate the productivity of sweet potatoes under different doses of chicken manure, with and without liming, comparing to the use of chemical fertilizer NPK, in very clayey soil, from the perspective of economic efficiency. The experiment was conducted in the field from September 2019 to March 2020 in Manaus, Amazonas, Brazil. The experimental design was in randomized blocks with four replications, in a split-plot scheme $2 \times 5+1$ (presence or absence of liming; five doses of chicken manure; and NPK, respectively. The evaluated parameters were: total and commercial productivity; number of total and commercial tuberous roots; harvest index; individual fresh mass, length, and diameter of tuberous roots. The effect of chicken manure was not influenced by the liming and there are no differences in agronomic values related to NPK. The dose of chicken manure that results in maximum production of the queen sweet potato variety is approximately $13 \mathrm{tha}^{-1}$, producing $25.2 \mathrm{tha}^{-1}$, while the resulting dose in maximum profit is approximately $12 \mathrm{t} \mathrm{ha}^{-1}$ with a production of the $25.1 \mathrm{t} \mathrm{ha}^{-1}$. The selling production directly to the final consumer increased profit by approximately $57.3 \%$. Purchasing the input directly from the manufacturer reduced costs by approximately $74.5 \%$. The use of chicken manure has a greater economic advantage compared to NPK in very clayey soil.
\end{abstract}

Keywords: economic viability, chemical fertilization, organic fertilization, presence and absence of liming, production theory

\section{Introduction}

Sweet potato (Ipomoea batatas (L.) LAM.) is a species of great socioeconomic relevance, being produced in most regions of Brazil. It has great popular acceptance and importance in food security due to its nutritional properties and easy cultivation. Its rusticity guarantees resistance to drought, little demand on nutrients and advantageous competition with weeds, for quickly covering the soil. In addition, to use in human food, sweet potatoes can be used in animal feed and ethanol production (Corrêa et al., 2016; Silva, Almeida, Alvim-Ferraz, \& Dias, 2018; Suparno, Prabawardani, \& Pattikawa, 2016; Vizzotto, Pereira, Castro, Raphaelli, \& Krolow, 2017).

However, the national productivity of sweet potatoes is considered to be low, considering the potential of the crop. Fact justified by the low technological level used in the crops, mainly regarding soil correction and fertilization (FAO, 2018; Oliveira et al., 2017). Organic fertilization is an affordable and efficient alternative to produce with a good profit margin, especially for properties located very far from large urban centers, with have difficult logistics, in which chemicals arrive at higher prices (Bezerra, Costa, \& Santos, 2020; Bulegon, Castagnara, Zoz, Oliveira, \& Souza, 2012).

Organic fertilization has several advantages compared to chemical fertilization. It improves as physical and biological conditions of the soil; presents an economic advantage for the small rural producer, since it reduces the dependence on industrial inputs and makes the plant less susceptible to pests and diseases, according to the theory of trophobiosis (Lin et al., 2019; Natalli, Munaretto, Bianchini, \& Henkes, 2020; Primavesi, 2014). 
Among the most widely used organic fertilizers, chicken manure is one of the most accessible fertilizers for family farmers because it is produced in large volumes and has low cost. In addition to providing savings for farmers, the use of manure from laying hens as fertilizer constitutes a destination for farm residues, without polluting soil and water resources, resulting in additional revenue and environmental conservation (Guimarães et al., 2016; Lima, Braga, Lourenzani, \& Forti, 2016).

It has been found that chicken manure increases the productivity of sweet potatoes, applied alone, or combined with chemical fertilizer (Rós, Narita, \& Hirata, 2014). However, it is noteworthy that the maximum physical production does not correspond to the production of maximum economic efficiency. This can be understood by analyzing the classic production function, which is divided into three phases, in which (I) marginal productivity is maximum (Pma), the curve presents its greatest slope, meaning the maximum contribution of each unit to more input in the total physical production, failing to add input at this stage means failing to generate profit; (II) Pma is decreasing and greater than zero, that is, there are decreasing increases, at this stage is the maximum profit; (III) Pma is negative, excess input reduces the amount of physical production (Varian, 2000; Debertin, 1986; Strassburg, Oliveira, Piacenti, \& Piffer, 2014). Thus, it is recommended to use economic parameters in scientific experiments to assist in the accuracy of the inferences made in the works.

Given the above, this work aims to evaluate the productivity of sweet potatoes under different doses of chicken manure, with and without liming, comparing to the use of chemical fertilizer NPK from the perspective of economic efficiency.

\section{Method}

\subsection{Experiment Location}

The experiment was carried out at the Experimental Farm of the Federal University of Amazonas $\left(2^{\circ} 39^{\prime} \mathrm{S}\right.$ and $\left.60^{\circ} 3^{\prime} \mathrm{W}\right)$. According to the Köppen classification, it has an Am, tropical, hot and humid climate, with average annual rainfall and temperature of 25 to $28^{\circ} \mathrm{C}$ and $2,100 \mathrm{~mm}$, respectively, and relative humidity of air around 84 to $90 \%$ (Ribeiro et al., 1999).

The chemical and physical characteristics of the soil in the 0 to $20 \mathrm{~cm}$ layer in pre-installation of the experiment

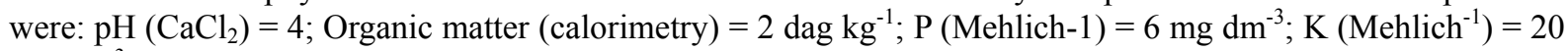
$\mathrm{mg} \mathrm{dm}{ }^{-3} ; \mathrm{Ca}(\mathrm{KCl})=0.5 \mathrm{cmol}_{\mathrm{c}} \mathrm{dm}^{-3} ; \mathrm{Mg}(\mathrm{KCl})=0.3 \mathrm{cmol}_{\mathrm{c}} \mathrm{dm}^{-3} ; \mathrm{Al}(\mathrm{KCl})=1.1 \mathrm{cmol}_{\mathrm{c}} \mathrm{dm}^{-3} ; \mathrm{H}+\mathrm{Al}(\mathrm{SMP})=$ 6.4; Sum of bases $=0.85 \mathrm{cmol}_{\mathrm{c}} \mathrm{dm}^{-3}$; Effective cation exchange capacity $=1.95 \mathrm{cmol}_{\mathrm{c}} \mathrm{dm}^{-3}$; Cation exchange capacity at $\mathrm{pH} 7=7.25 \mathrm{cmol}_{\mathrm{c}} \mathrm{dm}^{-3}$; Aluminium saturation $=56.37 \%$; Base saturation percentage $=11.74 \%$; sand $=10.7 \%$; silt $=18 \%$; clay $=71.3$, configuring a very clayey texture. The area was prepared with subsoiler, $35 \mathrm{~cm}$ high windrows were made (Rós, 2017).

\subsection{Experimental Design}

The experimental design was in randomized blocks with four replications, in a split-plot scheme $2 \times 5+1$ (presence or absence of liming; five doses of chicken manure; and additional treatment, configured as the defined NPK dose according to soil analysis and calibrated for the crop, respectively). In the main plot, liming was tested and in the subplots, fertilizer doses (chicken manure and NPK) were tested.

\subsection{Implementation of the Experiment}

The experiment was implemented in the field in September 2019. In the plots with limes, a dose of $3.8 \mathrm{t} \mathrm{ha}^{-1}$ of dolomitic limestone with $92.38 \%$ Relative Power of Total Neutralization was applied, according to the method of raising the base saturation to a value of $60 \%$. The application was made in the windrows 60 days before planting. The dose of NPK was $1.5 \mathrm{t} \mathrm{ha}^{-1}$ in formulation 4-14-8; considering the levels of $\mathrm{P}$ (medium) and $\mathrm{K}$ (low) in the soil and calibration for the crop was carried out, which resulted in a dose of $60 \mathrm{~kg} \mathrm{ha}^{-1}$ of N, $120 \mathrm{~kg} \mathrm{ha}^{-1}$ of $\mathrm{P}_{2} \mathrm{O}_{5}$ and $90 \mathrm{~K}_{2} \mathrm{O} \mathrm{kg} \mathrm{ha}{ }^{-1}$ (Silva, Lopes, \& Magalhães, 2008).

Chicken manure from a commercial farm had the following composition on a dry basis $\left(65^{\circ} \mathrm{C}\right): \mathrm{pH}\left(\mathrm{CaCl}_{2}\right)=$ $7.5 ; \mathrm{N}=2.41 \% ; \mathrm{P}_{2} \mathrm{O}_{5}=8.71 \% ; \mathrm{K}_{2} \mathrm{O}=3.38 \% ; \mathrm{Ca}=22.45 \% ; \mathrm{Mg}=0.97 \% ; \mathrm{S}=0.75 \%$; Organic Matter $=29.67 \%$; $\mathrm{C}=14.92 \% ; \mathrm{C} / \mathrm{N}=6 ; \mathrm{Cu}=104 \mathrm{mg} \mathrm{kg}^{-1} ; \mathrm{Mn}=636 \mathrm{mg} \mathrm{kg}^{-1} ; \mathrm{Zn}=5,121 \mathrm{mg} \mathrm{kg}^{-1} ; \mathrm{B}=10 \mathrm{mg} \mathrm{kg}^{-1} ; \mathrm{Na}=11,933$ $\mathrm{mg} \mathrm{kg}^{-1}$. The evaluated doses were (D1) 0 , (D2) 5, (D3) 10, (D4) 15 , (D5) $20 \mathrm{t} \mathrm{ha}^{-1}$ of chicken manure tanned with $13.42 \%$ moisture and density of $0.87{\mathrm{~g} . \mathrm{cm}^{-3}}^{-3}$. Fertilizers were applied to the windrows at the time of planting.

Each plot consisted of six windrows (subplots) with 12 plants per windrow. The experiment had a total of 768 plants. Five central plants of each plot were evaluated. 
The spacing adopted was $0.3 \mathrm{~m}$ between plants; $0.9 \mathrm{~m}$ between windrows (Rós, 2017); $2.7 \mathrm{~m}$ between plots; and $2.5 \mathrm{~m}$ between blocks. The total area of the plot was $20.79 \mathrm{~m}^{2}(6.3 \mathrm{~m} \times 3.3 \mathrm{~m})$, the block was $50.49 \mathrm{~m}^{2}(15.3 \mathrm{~m} \times$ $3.3 \mathrm{~m})$, the experiment was $316.71 \mathrm{~m}^{2}(20.7 \mathrm{~m} \times 15.3 \mathrm{~m}) .30 \mathrm{~cm}$ branches of the Rainha variety were used, one of the most cultivated in the State of Amazonas (Barrera, 1989; Cavalcante, Nascimento, \& Rocha, 2017; Filgueira, 2008).

\subsection{Evaluated Parameters}

The harvest and evaluation of the experiment were carried out in March 2020. The harvest was carried out 180 days after planting since, in tropical soils the later harvest results in higher yields when compared to the usual four to five months after planting (Oliveira et al., 2017). The following parameters were evaluated: total productivity (TP) and commercial productivity (CP) in $\mathrm{t} \mathrm{ha}^{-1}$, followed by economic analysis of fertilization; number of total tuberous roots (NTR) and number of commercial tuberous roots (NCR) per plant; harvest index (HI) in percentage; of each tuberous root, the individual fresh mass (IFM) was expressed in g, length (L) and diameter (D) in $\mathrm{cm}$. Tuberous roots were considered to have fresh mass equal to or greater than $40 \mathrm{~g}$, and commercial roots were those with fresh mass between 80 and $800 \mathrm{~g}$ (Rós, 2017).

The harvest index was obtained by the relation between the dry mass of the tuberous roots and the total dry mass of an entire plant per subplot, with a value expressed as a percentage. To quantify the biomass, samples of approximately $100 \mathrm{~g}$ of branches and tuberous roots were obtained, which were initially weighed and sanitized for drying in an oven with air circulation, at a temperature of $65^{\circ} \mathrm{C}$ until constant weight, approximately 72 hours (Rós, 2017; Santos Neto, T. O. Silva, Blank, J. O. Silva, \& Araújo Filho, 2017).

The economic analysis of fertilization was made according to the Production Theory by the production function in the factor-product model, under condition ceteris paribus (all the more constant), which can be represented mathematically as (Varian, 2000):

$$
\mathrm{Y}=\mathrm{f}(\mathrm{x} 1, \mathrm{x} 2, \ldots \mathrm{xn})
$$

The dose of chicken manure was calculated which results in maximum production and maximum profit, as well as average product (Pme), costs, and profits in the scenarios of buying the input and selling the production with and without intermediaries. A comparison was made regarding the use of NPK (Varian, 2000; Debertin, 1986; Strassburg et al., 2014).

The dose (x) and its referred production (y) which results in maximum physical production (Ymax) were calculated by equating the production function (regression analysis equation) to zero and replacing the $\mathrm{x}$ found in the production function (Varian, 2000; Debertin, 1986; Strassburg et al., 2014):

$$
\mathrm{Y}^{\prime}=0
$$

The dose (x) and its referred production (y) that results in maximum profit (Lmax) were calculated by equating the derivative of the production function to the value of the marginal product-VPma, where Px = input price and Py = production (Varian, 2000; Debertin, 1986; Strassburg et al., 2014):

$$
\begin{aligned}
& Y^{\prime}=\mathrm{VPma} \\
& \mathrm{Y}^{\prime}=\mathrm{Px} / \mathrm{Py}
\end{aligned}
$$

Where, $Y=$ quantity of production, $P y=$ unit price of $y, x=$ quantity of inputs, $P x=$ unit price of inputs; the average product (Pme), cost (C), and profit (L) were calculated. Prices were practiced in the local market in January 2020 (Varian, 2000; Debertin, 1986; Strassburg et al., 2014).

$$
\begin{gathered}
\text { Pme }=y / x \\
C=P x \cdot x \\
L=P y \cdot y-P x \cdot x
\end{gathered}
$$

The $40 \mathrm{~kg}$ bag of chicken manure cost $\mathrm{R} \$ 9.00$ purchased from the manufacturer (laying hens farm) and $\mathrm{R} \$ 15.90$ purchased from the intermediate (input store). The value of the $50 \mathrm{~kg}$ bag of NPK (4-14-8) costs $\mathrm{R} \$ 105.00$ at the input store. The price per kilo of sweet potato paid to the producer by the intermediary was $\mathrm{R} \$ 2.60$; the price charged at fairs (direct sale to consumers) was $\mathrm{R} \$ 4.00$. For the calculations, the values were standardized in tons (CONAB, 2020). 


\subsection{Statistical Analysis}

The data regarding the number of total and commercial tuberous roots were transformed $\left(\mathrm{x}^{0.5}\right)$ to meet the assumptions of normality and homogeneity. These tests were performed using the Sisvar and Minitab ${ }^{\circledR}$ Statistical Software programs, respectively (Ferreira, 2011; Minitab, 2019).

Using the Sisvar software, all data were subjected to analysis of variance and F test (5\% probability). Regression analysis was performed for results related to chicken manure doses. Contracts analysis was carried out to compare the use of chicken manure, the zero dose of chicken manure and chemical fertilization. The graphics were generated by an algorithm developed in Python using the Matplotlib library (Ferreira, 2011; Hunter, 2007).

\section{Results and Discussion}

Liming, as well as its interaction with chicken manure, did not influence any of the evaluated parameters. Only the subplot had a significant effect on agronomic parameters, except for the harvest index and diameter (Table $1)$.

Table 1. p-value of the sources of variation for each parameter evaluated in the sweet potato crop under the influence of five doses of chicken manure with and without liming

\begin{tabular}{lllll}
\hline \multirow{2}{*}{ Evaluated parameters } & \multicolumn{3}{c}{$\boldsymbol{p}$-value } \\
\cline { 2 - 5 } & Block & Plot & Subplot & Plot*Subplot \\
\hline Total productivity & 0.8000 & 0.3540 & $<0.0001^{*}$ & 0.6898 \\
Commercial productivity & 0.3949 & 0.7263 & $0.0002^{*}$ & 0.9510 \\
$\mathrm{~N}^{\mathrm{o}}$ total tuberous roots per plant & 0.5081 & 0.8463 & $0.0002^{*}$ & 0.8337 \\
$\mathrm{~N}^{\mathrm{o}}$ commercial tuberous roots per plant & 0.3644 & 0.8659 & $0.0021^{*}$ & 0.8660 \\
Harvest índex & 0.2808 & 0.4858 & 0.0735 & 0.3371 \\
Tuberous roots individual fresh mass & 0.6321 & 0.4816 & $0.0001^{*}$ & 0.3225 \\
Length of tuberous root & 0.8672 & 0.6013 & $0.0004^{*}$ & 0.4201 \\
Diameter of tuberous root & 0.2495 & 0.7101 & 0.1015 & 0.1040 \\
\hline
\end{tabular}

Since chicken manure raises the pH of the soil (Eguchi et al., 2016), it was expected that the interaction between plots and subplots would be significant, so that it was possible to find the dose of chicken manure without using liming that would result in maximum profit and another, lower dose, associated with liming. This did not happen, possibly due to the liming function making minerals available (Raij, 2011).

Thus, the lack of liming effect at zero dose can be explained by this dose not providing nutrients and the soil being of low fertility, also justifying its inferiority to the other treatments applied in the subplots. In addition, the crop is able to exploit the soil well in a way that expresses high productivity even in soils without high fertility, being dispensable in liming. However, the studies found in the literature related to sweet potato fertilization show contradictory results, and local studies are essential to define the ideal fertilizer dose (Oliveira et al., 2017). The doses that resulted in higher total productivity (38.0504 tha ${ }^{-1}$ of potatoes) and commercial $\left(25.153 \mathrm{t} \mathrm{ha}^{-1}\right.$ of potatoes) were 14.895 and $12.708 \mathrm{tha}^{-1}$ of chicken manure, respectively (Figure 1). 


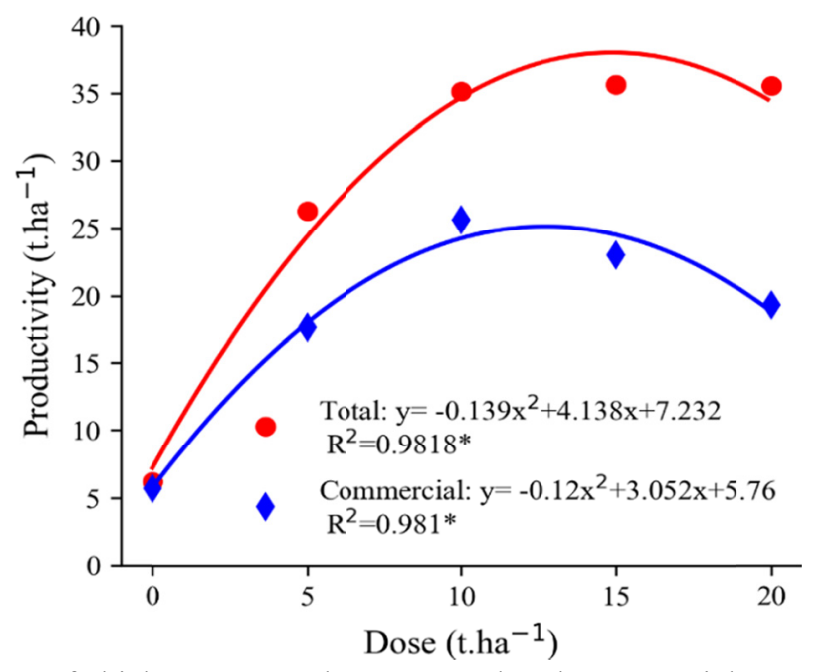

Figure 1. Effect of chicken manure doses on total and commercial sweet potato yield

Similar results were found by Cecílio Filho, Nascimento, Silva, and Vargas (2016), who, testing $\mathrm{K}_{2} \mathrm{O}$ doses, obtained TP $=38$ and $\mathrm{CP}=24.3 \mathrm{tha}^{-1}$ of the 'Beauregard' variety, respectively. Rós et al. (2014) used chicken manure for fertilizing sweet potatoes, without specifying the variety or cultivar, and obtained total $\left(26.6 \mathrm{tha}^{-1}\right)$ and commercial $\left(23.6 \mathrm{tha}^{-1}\right)$ productivity in doses of 7.79 and $5.84 \mathrm{t} \mathrm{ha}^{-1}$, respectively.

Comparing with other studies with the Rainha variety, the present research presented productivity values superior to those found by Cavalcante et al. (2017), which reached $5.60 \mathrm{tha}^{-1}$ by testing doses of $\mathrm{P}_{2} \mathrm{O}_{5}$; and by Brito et al. (2006), who obtained TP $=14.8$ and $\mathrm{CP}=8.4 \mathrm{tha}^{-1}$ from doses of $\mathrm{K}_{2} \mathrm{O}$.

These divergences can be explained by the distinct edaphoclimatic characteristics of the different research locations, as the growth, development, and productivity of tuberous roots are influenced by the physical, chemical and biological characteristics of the soil, air temperature, photoperiod, and solar radiation (Erpen, Streck, Uhlmannm, Freitas, \& Andriolo, 2013; Medeiros, Pereira, \& Miranda, 1990; Villordon, Solis, Labonde, \& Clark, 2010). The chemical composition of manure used in fertilization also interferes with productivity (Filho et al., 2013). Possibly, chicken manure promoted an increase in total and commercial productivity due to the mineralization process of the organic matter in the manure resulting in an increase in the $\mathrm{pH}$ and in the levels of macro and micronutrients in the soil, such as N, P, K, Ca, Mg and B (Rós et al., 2014).

Commercial production is the parameter that directly results in economic return. Then, from its quadratic equation $\left(-0.120079 \mathrm{x}^{2}+3.052021 \mathrm{x}+5.760071\right)$ the dose of chicken manure was calculated, which results in sweet potato production under the conditions of maximum physical production and profit maximum, as well as the average physical product, costs and profits, in the scenarios of buying the input and selling the production directly and through intermediaries. A comparison was made with the use of NPK for the two production sales scenarios. The purchase price of the NPK was practiced by an intermediary, as there is no factory for this input in the region (Table 2). 
Table 2. Economic scenarios for fertilization with chicken manure compared to the use of NPK in sweet potato culture

\begin{tabular}{|c|c|c|c|c|c|c|c|}
\hline Fertilizer & $P x(t)$ & $P y(t)$ & $x\left(\mathrm{tha}^{-1}\right)$ & $y\left(t h^{-1}\right)$ & Pme & Cost & Profit \\
\hline \multirow{8}{*}{ Chicken manure } & \multirow{4}{*}{225.00} & $2,600.00$ & \multirow{2}{*}{12.708 (Ymax.) } & \multirow{2}{*}{25.153} & \multirow{2}{*}{1.979} & \multirow{2}{*}{$2,859.30$} & $62,538.80$ \\
\hline & & $4,000.00$ & & & & & $97,752.70$ \\
\hline & & $2,600.00$ & 12.348 (Lmax.) & 25.138 & 2.036 & $2,778.30$ & $62,580.50$ \\
\hline & & $4,000.00$ & 12.474 (Lmax.) & 25.147 & 2.016 & $2,806.65$ & $97,781.35$ \\
\hline & \multirow{4}{*}{397.50} & $2,600.00$ & \multirow{2}{*}{12.708 (Ymax.) } & \multirow{2}{*}{25.153} & \multirow{2}{*}{1.979} & \multirow{2}{*}{$5,051.43$} & $60,346.37$ \\
\hline & & $4,000.00$ & & & & & $95,560.57$ \\
\hline & & $2,600.00$ & 12.072 (Lmax.) & 25.104 & 2.079 & $4,798.62$ & $60,471.78$ \\
\hline & & $4,000.00$ & 12.294 (Lmax.) & 25.132 & 2.044 & $4,886.86$ & $95,641.14$ \\
\hline \multirow{2}{*}{ NPK } & \multirow{2}{*}{2100.00} & $2,600.00$ & \multirow{2}{*}{1.5} & \multirow{2}{*}{18.935} & \multirow{2}{*}{12.623} & \multirow{2}{*}{$3,150.00$} & $46,078.00$ \\
\hline & & $4,000.00$ & & & & & $72,590.00$ \\
\hline
\end{tabular}

Note. $\mathrm{Px}=$ price of the ton of the input; $\mathrm{Px}=\mathrm{R} \$ 225.00$, the price paid to the manufacturer; $\mathrm{Px}=\mathrm{R} \$ 397.50$, the price paid to the merchant. $\mathrm{Py}=$ price of the product; $\mathrm{Py}=\mathrm{R} \$ 2,600.00$, the price paid to the producer; $\mathrm{Py}=$ $\mathrm{R} \$ 4,000.00$, the price paid by the final consumer. $\mathrm{x}=$ quantity of input in ton; Ymax: amount of input for maximum physical production; Lmax: amount of input for maximum profit. y: production. Pme $=$ average physical product. Production function of sweet potatoes fertilized with manure from laying hens: $0.120079 \mathrm{x}^{2}+$ $3.052021 \mathrm{x}+5.760071$. NPK dose defined according to soil analysis. Prices in the local market in January 2020 .

The application of the $12,708 \mathrm{tha}^{-1}$ dose resulted in a cost of $\mathrm{R} \$ 2,859.30$ if the input is purchased directly from the manufacturer, that is, at the laying hens farm. However, if it is acquired from intermediaries, in an agricultural products store, there is an increase of $76.66 \%$ in cost, which is now R $\$ 5,051.43$. Analyzing the variation of Py in the scenario of the price paid to the producer, the profit falls from $\mathrm{R} \$ 62,538.80$ to $\mathrm{R} \$ 60,346.37$, a loss of $3.5 \%$. In the scenario of selling direct production to the final consumer, as in fairs, the profit proceeds from $\mathrm{R} \$ 97,752.7$ to $\mathrm{R} \$ 95,560.57$, decreasing by $2.24 \%$.

If the sale of sweet potatoes is direct to the final consumer, varying the Px, it results in a profit increase of $56.31 \%$ and $58.35 \%$ for the cases of maximum commercial production with input purchased from the manufacturer and the intermediary, respectively (Table 2).

However, the dose of greater physical production does not represent the dose of greater economic efficiency. For this reason, the doses that result in maximum profit were found, corresponding the derivative of the production function to the Value of the Marginal Product (VPma = Px/Py) (Strassburg et al., 2014).

In the condition of the VPma $=0.0865$, purchase of direct input from the manufacturer $(\mathrm{Px}=\mathrm{R} \$ 225.00)$ and sale of production to the intermediary ( $\mathrm{Py}=\mathrm{R} \$ 2,600.00)$, the maximum profit was $\mathrm{R} \$ 62,579.46$ in the dose $12,348 \mathrm{tha}^{-1}$, which resulted in production of $25,138 \mathrm{tha}^{-1}$. If this production is sold directly to the consumer (Px $=4,000.00$ ), the profit becomes $\mathrm{R} \$ 97,781.35$, about 56.2\% higher, with the $\mathrm{x}=12.474 \mathrm{tha}^{-1}$ and the $\mathrm{y}=25.147$ $\mathrm{t} \mathrm{ha}^{-1}$ (Table 2).

However, if the input is purchased at an agricultural products store $(\mathrm{Px}=\mathrm{R} \$ 397.50)$, with VPma $=0.152$, considering the production price paid to the producer $(\mathrm{Py}=\mathrm{R} \$ 2,600.00)$, the maximum profit dose becomes $12.072 \mathrm{t} \mathrm{ha}^{-1}$ of chicken manure, producing $25.104 \mathrm{t} \mathrm{ha}^{-1}$ of sweet potato. There is an increase of $72.7 \%$ in the cost of production, which results in a loss of $3.4 \%$ in profit, since the new values of cost and profit are $\mathrm{R} \$ 4,798.62$ and $\mathrm{R} \$ 60,471.78$, respectively.

Modifying this scenario for direct sales of production to the final consumer $(\mathrm{Py}=\mathrm{R} \$ 4,000.00)$, with VPma $=$ 0.0994 , the new quantities of $\mathrm{x}$ and $\mathrm{y}$ for maximum profit are $12,294 \mathrm{tha}-{ }^{1}$ and $25,132 \mathrm{t} \mathrm{ha}^{-1}$, respectively. Profit was $\mathrm{R} \$ 95,641.14$, an increase of $58.16 \%$, varying the Px. But there was a loss of $2.19 \%$ in profit and an increase of $74.1 \%$ in costs compared to the acquisition of direct input from the manufacturer, varying the Py (Table 2).

The NPK in the dose according to the soil analysis and calibrated for the sweet potato culture $\left(1.5 \mathrm{t} \mathrm{ha}^{-1}\right)$, resulted in a production of $18,935 \mathrm{t} \mathrm{ha}^{-1}$ of commercial tuberous roots as the cost of $\mathrm{R} \$ 3,150.00$. The profit was $46,078.00$ and $72,590.00$, considering the price paid to the producer and direct sale to the final consumer, respectively, representing $57.54 \%$ difference between them.

Considering the dose of chicken manure that results in greater economic profit, when analyzing the scenario of selling the production to the intermediate and buying the input from the manufacturer, it presented a profit $35.8 \%$ 
higher than the NPK and the cost of $11.8 \%$ less than NPK.

In the scenario of selling production to the intermediary and buying the input from the intermediary, profit was $31.2 \%$ higher than the NPK, with a cost $52.3 \%$ higher than the NPK. And in the analysis of the scenario of selling the production to the final consumer and purchasing the input from the manufacturer, it showed a profit $54.7 \%$ higher than the NPK and the cost $10.9 \%$ lower than the NPK. While in the scenario of selling the production to the final consumer and buying the input from the intermediary, the profit was 50\% higher than the NPK, with a cost $55.1 \%$ higher than the NPK.

Thus, in relation to the use of NPK, chicken manure presents, on average, a 33.5\% higher profit if the production is sold to the intermediate, and $52.3 \%$ higher if the production is sold to the final consumer; and cost $53.7 \%$ lower if the input is purchased directly from the manufacturer and $11.4 \%$ lower if the input is purchased at an input store (Table 2).

So, despite the unitary contribution (Pme) of the chicken manure is 6.3 times less than the Pme of the NPK (Table 2), chicken manure still has a greater economic advantage in very textured soil clayey.

All doses that expressed the maximum physical production and maximum profit in commercial productivity, in all evaluated scenarios, presented approximately 2.6 total tuberous roots per plant, of these, 2.1 are commercial roots. These values coincided with Ymax for the number of total tuberous roots and the number of commercial tuberous roots per plant. From the dose of $1.5 \mathrm{t} \mathrm{ha}^{-1}$ on average, there is at least one commercial root per plant (Figure 2).

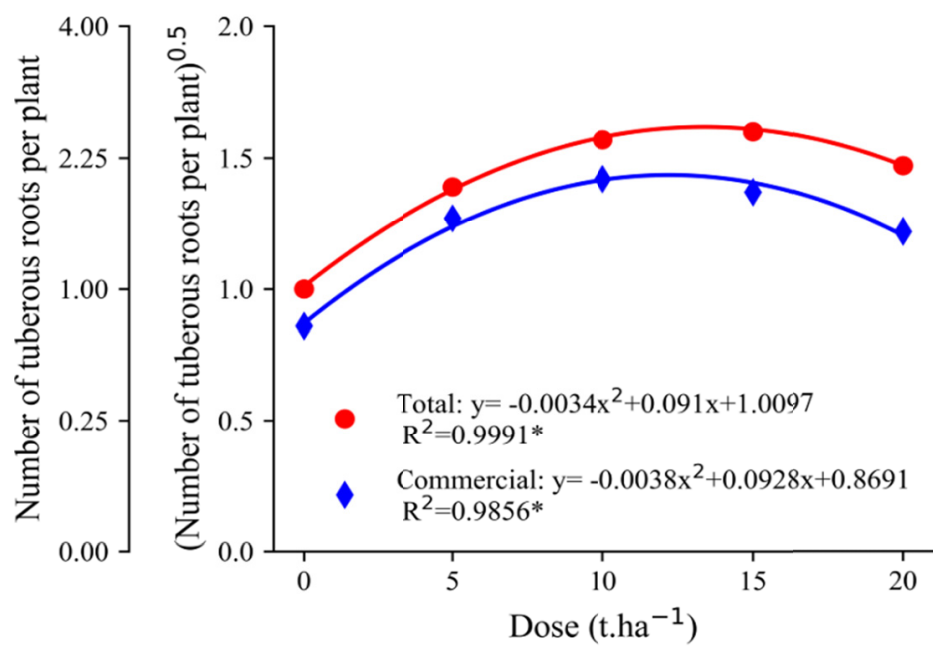

Figure 2. Effect of chicken manure doses on the number of total and commercial sweet potato tuber roots

The NTR and NCR of the present study are consistent with other results found in the literature. Silva, Suinaga, Ponijaleki, and Amaro (2015), evaluated the performance of sweet potato cultivars and obtained the average number of total and commercial roots equal to 4.39 and 1.38, respectively in 2012, in 2013, these values were 3.53 and 1.74, respectively. Câmara et al. (2013), evaluated the performance of sweet potato branches in a conventional and in vitro manner and obtained the average value of total and commercial roots in a conventional manner ranging from 1.5 to 4.75 and 1 to 3.75 roots per plant, respectively.

Oliveira, Barbosa, Cavalcante, Pereira, and Oliveira (2007), evaluated the production of sweet potatoes fertilized with bovine manure with and without biofertilizer and reached the maximum number of commercial roots per plant with values of 2.0 and 1.7 roots, at doses of 26 and $25 \mathrm{tha}^{-1}$, respectively. The variation in values is related to the different sweet potato varieties used in each search and their different planting locations (Silva, Ponijaleki, \& Suinaga, 2012; Silva et al., 2015).

The advantage of using chicken manure fertilization is confirmed by the analysis of contrasts, as there was no significant difference in relation to NPK in the recommended dose. Three contrasts were analyzed, (1) zero dose of chicken manure, which represents the absence of fertilization versus chemical fertilization with NPK; (2) NPK versus chicken manure; and (3) no fertilization versus chicken manure (Table 3).

Chemical fertilization was superior to the absence of fertilization for all parameters evaluated, except for NCR, 
which showed no statistical difference. The use of chicken manure in comparison to the absence of fertilization was higher for all parameters evaluated, except for the harvest index, which did not show statistical difference. (Table 3).

Table 3. Contrast analysis for comparison between fertilization with chicken manure, zero dose of chicken manure and chemical fertilization in the agronomic parameters of sweet potato crop

\begin{tabular}{|c|c|c|c|c|c|c|c|c|}
\hline Treatment & TP & $\mathbf{C P}$ & NTR & NCR & HI & IFM & $\mathbf{L}$ & D \\
\hline T0: $1.5 \mathrm{t} \mathrm{ha}^{-1} \mathrm{NPK}$ & 27.06 & 18.93 & 1.81 & 1.45 & 69.27 & 342.82 & 12.69 & 8.21 \\
\hline $\mathrm{T} 1: 0 \mathrm{tha}^{-1} \mathrm{CM}$ & 6.23 & 5.70 & 1.00 & 0.74 & 56.44 & 177.7 & 9.41 & 6.95 \\
\hline $\mathrm{T} 2: 5 \mathrm{tha}^{-1} \mathrm{CM}$ & 26.31 & 17.69 & 1.93 & 1.62 & 65.37 & 300.47 & 12.26 & 7.84 \\
\hline T3: $10 \mathrm{tha}^{-1} \mathrm{CM}$ & 35.14 & 25.64 & 2.46 & 2.03 & 68.81 & 325.00 & 12.08 & 8.01 \\
\hline T4: $15 \mathrm{t} \mathrm{ha}^{-1} \mathrm{CM}$ & 35.64 & 23.03 & 2.56 & 1.88 & 61.9 & 325.61 & 12.59 & 7.4 \\
\hline T5: $20 \mathrm{t} \mathrm{ha}^{-1} \mathrm{CM}$ & 35.57 & 19.29 & 2.16 & 1.5 & 53.47 & 353.64 & 13.66 & 7.71 \\
\hline Contrasts [coefficients] & \multicolumn{8}{|c|}{ Constrast estimation } \\
\hline T1 [+1] vs. T0 [-1] & $-20.8^{*}$ & $-13.2 *$ & $-0.34 *$ & -0.3 & $-12.8^{*}$ & $-165^{*}$ & $-3.28 *$ & $-1.3^{*}$ \\
\hline $\mathrm{T} 1[-4]$ vs. $\mathrm{T} 2+\mathrm{T} 3+\mathrm{T} 4+\mathrm{T} 5[+1+1+1+1]$ & $26.93 *$ & $15.71 *$ & $0.50 *$ & $0.47^{*}$ & 5.95 & $148.48^{*}$ & $3.24 *$ & $0.78^{*}$ \\
\hline $\mathrm{T} 0[-4]$ vs. $\mathrm{T} 2+\mathrm{T} 3+\mathrm{T} 4+\mathrm{T} 5[+1+1+1+1]$ & 6.1 & 2.48 & 0.16 & 0.12 & -6.9 & -16.6 & -0.05 & -0.5 \\
\hline
\end{tabular}

Note. ${ }^{*}$ significance at $5 \%$ probability for each evaluated parameter. $\mathrm{TP}=$ total yield of tuberous roots; $\mathrm{CP}=$ commercial productivity of tuberous roots; NTR = total tuberous roots per plant; NCR = total commercial tuberous roots per plant; $\mathrm{HI}=$ harvest index; IFM = fresh mass of the individual tuberous root; $\mathrm{L}=$ length of tuberous roots; $\mathrm{D}=$ diameter of tuberous roots. The data for the NTR and NCR variables transformed by $\mathrm{x}^{0.5}$ underwent an inverse operation $\left(\mathrm{x}^{2}\right)$ to be expressed in the table.

Regarding the harvest index, the values vary from $53.47 \%$ (without fertilization) to 69.27 (NPK), the doses of manure of hen resulted in intermediate values. The use of NPK resulted in a greater investment of the plant in tuberous roots than in aerial parts when compared to the absence of fertilization (Table 3). But with regard to manure, there was no significant difference between doses to be performed for regression analysis (Table 1).

These results are in agreement with those found in related research. Queiroga, Santos, Menezes, Vieira, and Silva (2007) evaluated sweet potato cultivars according to different harvest times and obtained HI values equal to $57.18 \% ; 49.21 \%$ and $49.74 \%$ for cultivars ESAM 1, ESAM 2 and ESAM 3, respectively. Santos Neto et al. (2017) obtained HI values equal to $80.17 \%$; $55.55 \%$ and $68.25 \%$ for clones IPB-052, IPB-075 and IPB-149, respectively, fertilized with doses of $\mathrm{N}$ with 150 days of harvest. Moreira, Queiroga, Júnior, and Santos (2011), evaluated the morphophysiological and productive characteristics of sweet potato cultivars and obtained the highest and lowest HI value equal to 49.32\% (cultivar Seu Antônio) and 18.84\% (cultivar Brazilândia White).

Sweet potatoes are commercialized by weight, thus, the parameter of economic importance is commercial productivity, the other parameters being only for characterization. The economic implication of the individual fresh root mass is implicit in commercial productivity, as it considers only those that are accepted by the consumer market, with the individual fresh mass of the tuberous root between $80 \mathrm{~g}$ and $800 \mathrm{~g}$ (Rós, 2017). Since the regression analysis expresses average values, boxplots were elaborated to better express the diversity of the IFM (Figure 3), as well as the length and diameter of each root (Figures 4A and 4B). It is worth mentioning that organic fertilization and chemistry did not differ from each other and were higher than zero doses for the IFM, L and D (Table 3). 


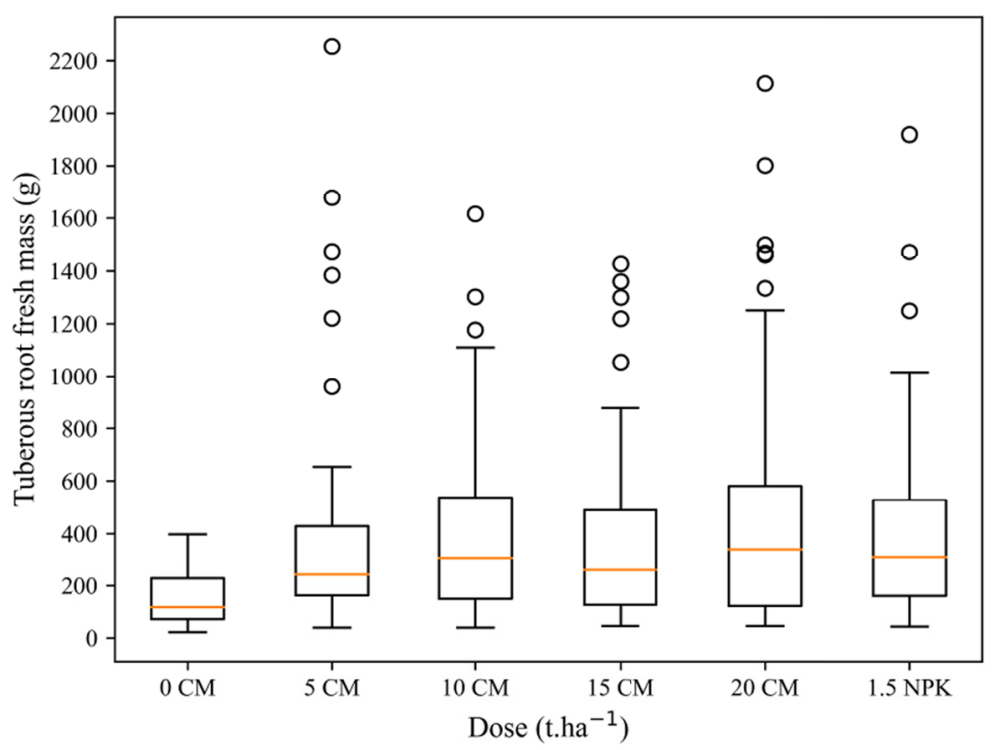

Figure 3. Effect of fertilization with chicken manure and NPK on the individual fresh mass of sweet potato tuber roots
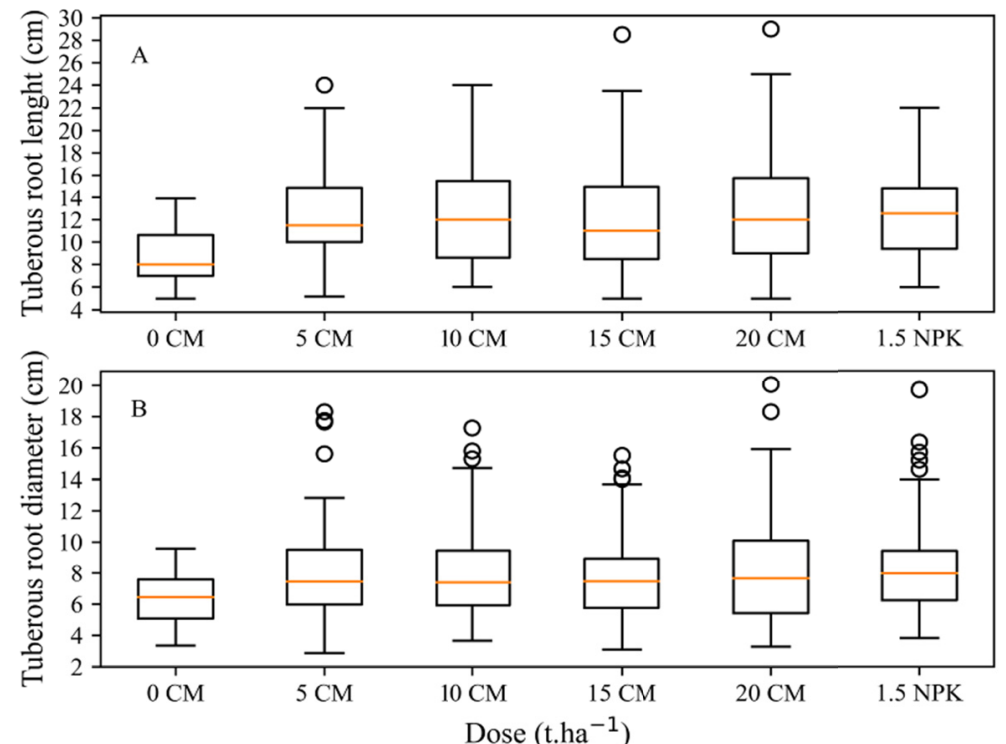

Figure 4. Effect of fertilization with chicken manure and NPK on the length (A) and diameter (B) of the sweet potato tuberous root

At the zero dose of chicken manure, the median was recorded at approximately $117 \mathrm{~g}$, indicating that $50 \%$ of the potatoes had lower IFM and 50\% had IFM greater than this value; in addition, 25\% (1st quartile) of the potatoes were not commercial, with values below $71 \mathrm{~g}$. The maximum IFM in this dose was approximately $396 \mathrm{~g}$, lower than the 3rd quartile of the other treatments, that is, at least $25 \%$ of the data of the other treatments were above the maximum IFM value of the zero dose. The treatments with fertilization (organic or chemical) presented a median between 200 and $400 \mathrm{~g}$, and 1st quartile in commercial value, varying from 120 to $168 \mathrm{~g}$ (Figure 3).

The data corroborate with research done by Oliveira et al. (2007), who obtained the average weight of the commercial roots with values 360 and $224 \mathrm{~g}$, for fertilization with bovine manure $\left(50 \mathrm{t}^{-1}\right)$ with presence and absence of biofertilizer, respectively. Alves et al. (2009), evaluated the yield of sweet potato, cultivar Rainha Branca, submitted to nitrogen fertilization and obtained values for average commercial root weight equal to 231 and $231.10 \mathrm{~g}$ for fertilization with ammonium and urea sulfate, respectively. Cavalcante et al. (2017), obtained the average weight of the sweet potato roots, cultivar Rainha, equal to $218.08 \mathrm{~g}$, using fertilization with doses of 
$\mathrm{P}_{2} \mathrm{O}_{5}$. These values varied due to the different fertilizers used.

Regarding the length at zero dose, the values ranged from 4.9 to $13.8 \mathrm{~cm}$, with a median of $8 \mathrm{~cm}$. Checking the 3rd quartile, $75 \%$ of the data were less than $10.7 \mathrm{~cm}$. The treatments that received fertilization had the $3 \mathrm{rd}$ quartile between 14.7 and $15.9 \mathrm{~cm}$ and $50 \%$ of the potatoes (range from the 1st to the 3rd quartile) showed 8.5 to $10<\mathrm{L}<14.8$ to $15.7 \mathrm{~cm}$, with median between 11 to $12.5 \mathrm{~cm}$ (Figure $4 \mathrm{~A}$ ).

As for the diameter in the absence of fertilization, the values were between 3.4 and $9.6 \mathrm{~cm}$. The median registered $6.4 \mathrm{~cm}$ and $75 \%$ of the data were less than $7.6 \mathrm{~cm}$. The other treatments presented the 3rd quartile in the range of 8 to $10.1 \mathrm{~cm}, 50 \%$ of the potatoes with 5.3 to $6.1<\mathrm{D}<8.9$ to $10.1 \mathrm{~cm}$, with medians ranging from 7.4 to $7.9 \mathrm{~cm}$, and respectively (Figure $4 \mathrm{~B}$ ).

Similar results were found by Rós (2017) evaluated the yield and shape of tuberous roots of sweet potatoes as a function of the number of buried buds, and presented an average of 13.2 and $5.7 \mathrm{~cm}$ in length and diameter, respectively. Carmona, Peixoto, Amaro, and Mendonça (2015) morphologically characterized 23 sweet potato genotypes, the average values between these genotypes were 15.62 and $5.45 \mathrm{~cm}$ for length and diameter, respectively. The diameter and length values vary according to the variety of potato used.

\section{Conclusion}

The absence of fertilization results in low values of total and commercial productivity; number of total and commercial tuberous roots; harvest index and individual fresh weight, length and diameter as compared to the use of chicken manure and/or NPK; resulting in low profit despite the zero cost of fertilization.

The effect of chicken manure was not influenced by liming and there are no differences regarding NPK in the recommended dose.

The dose of chicken manure that results in maximum production of the queen sweet potato variety is approximately $13 \mathrm{t} \mathrm{ha}^{-1}$, producing $25.2 \mathrm{t} \mathrm{ha}^{-1}$. However, the dose that results in maximum profit is approximately $12 \mathrm{t} \mathrm{ha}^{-1}$ with a production of $25.1 \mathrm{t} \mathrm{ha}^{-1}$. All doses aiming at maximum profit, in any scenario of purchase and sale of inputs, and the maximum productivity dose had 2.6 total tuberous roots and 2.1 commercial roots per plant.

The largest contribution to profit is due to Py compared to Px, since direct sales to the final consumer increase profit by approximately $57.3 \%$ in relation to sales to intermediaries. The purchase of direct input from the manufacturer instead of the intermediary reduces the cost by approximately $74.5 \%$ but increases the profit by only $2.2 \%$ considering the price paid to the producer, and by $3.4 \%$ for direct sale to the final consumer.

Regarding the use of NPK, chicken manure presents, on average, a $33.5 \%$ and $52.3 \%$ higher profit if the production is sold to the intermediary or the final consumer, respectively; with a cost of $53.7 \%$ lower and $11.4 \%$ higher if the input is purchased directly from the manufacturer or input store, respectively.

Therefore, although the chicken manure unit contribution (Pme) is 6.3 times smaller than the NPK's Pme, or chicken manure still presents a greater economic advantage in very clayey clay texture.

\section{Acknowledgements}

This study was financed in part by the Coordenação de Aperfeiçoamento de Pessoal de Nível Superior-Brasil (CAPES) and published with the financed support of the Programa de Apoio à Publicação de Artigos Científicos of the Fundação de Amparo à Pesquisa do Estado do Amazonas (PAPAC/FAPEAM).

\section{References}

Alves, A. U., Oliveira, A. P., Alves, E. U., Oliveira, A. N. P. de, Cardoso, E. de A., \& Matos, B. F. (2009). Manejo da adubação nitrogenada para batata-doce: fontes e parcelamento de aplicação. Ciência $e$ Agrotecnologia, 33(6), 1554-1559. https://doi.org/10.1590/S1413-70542009000600014

Barrera, P. (1989). Batata-doce: Uma das doze culturas mais importantes culturas do mundo. São Paulo, SP: Ícone editora LTDA.

Bezerra, T. da S., Costa, P. F. da, \& Santos, M. dos. (2020). Análise da sustentabilidade e viabilidade econômica de uma propriedade familiar em Pedro Gomes, MS. Holos Environment, 20(2), 168-185. https://doi.org/ 10.14295/holos.v20i2.12373

Brito, C. H., Oliveira, A. P de, Alves, A. U., Dorneles, C. S. M., Santos, J. F., \& Nóbrega, J. P. R. (2006). Produtividade da batata-doce em função de doses de $\mathrm{K}_{2} \mathrm{O}$ em solo arenoso. Horticultura Brasileira, 24(3). https://doi.org/10.1590/S0102-05362006000300010 
Bulegon, L. G., Castagnara, D. D., Zoz, T., Oliveira, P. S. R. de, \& Souza, F. H. (2012). Análise econômica na cultura do milho utilizando adubação orgânica em substituição à mineral. Ensaios e Ciência: Ciências Biológicas, Agrárias e da Saúde, 16(2), 81-91. Retrieved from http://www.redalyc.org/articulo.oa?id= 26025448007

Câmara, F. A. A., Grangeiro, L. C., Dombroski, J. L. D., Santos, M. A. dos S., Freitas, R. M. O. de, \& Freitas, F. C. L. de. (2013). Desempenho agronômico de cultivares de batata-doce oriundas de ramas produzidas de forma convencional e in vitro. Revista Brasileira de Ciêncoas Agrárias, 8(3), 370-374. https://doi.org/ 10.5039/agraria.v8i3a2353

Carmona, P. A. O., Peixoto, J. R., Amaro, G. B., \& Mendonça, M. A. (2015). Divergência genética entre acessos de batata-doce utilizando descritores morfoagronômicos das raízes. Horticultura Brasileira, 33(2). https://doi.org/10.1590/S0102-053620150000200017

Cavalcante, R. R., Nascimento, I. R. do, \& Rocha, R. N. C. da. (2017). Características produtivas de genótipos de batata doce em função de doses de fósforo em solos de terra firme no município de Careiro, AM. Tecnologia \& Ciência Agropecuária, 11(6), 17-23. Retrieved from http://ainfo.cnptia.embrapa.br/digital/ bitstream/item/171819/1/04-artigo-ce-0817-04-caracteristicas-produtivas-de-genotipos-de-batata-doce.pdf

Cecílio Filho, A. B., Nascimento, S. M. C., Silva, A. S. N., \& Vargas, P. F. (2016). Agronomic performance of sweet potato with different potassium fertilization rates. Horticultura Brasileira, 34(4). https://doi.org/ 10.1590/S0102-053620160421

CONAB. (2020). Preços agrícolas. Retrieved from http://sisdep.conab.gov.br/precosiagroweb

Corrêa, A. A., Backes, A. A., Fagundes, J. L., Barbosa, L. T., Sousa, B. M. L., Oliveira, V. S., \& Moreira, A. L. (2016). Caracterização da silagem da rama da batata doce emurchecida e adicionada de fubá de milho como aditivo. Boletim de Indústria Animal, 73(4), 272-280. https://doi.org/10.17523/bia.v73n4p272

Debertin, D. L. (1986). Agricultural production economics (p. 366). New York: MacMillian; London: Collier Macmillan.

Eguchi, E. S., Cecato, U., Muniz, A. S., Mari, G. C., Murano, R. A. C., \& Sousa Neto, E. L. de. (2016). Physical and chemical changes in soil fertilized with poultry manure with and without chiseling. Revista Brasileira de Engenharia Agrícola e Ambiental, 20(4), 316-321. https://doi.org/10.1590/1807-1929/agriambi.v20 $\mathrm{n} 4 \mathrm{p} 316-321$

Erpen, L., Streck, N. A., Uhlmannm, L. O., Freitas, C. P. de O. de, \& Andriolo, J. L. (2013). Tuberização e produtividade de batata-doce em função de datas de plantio em clima subtropical. Bragantia, 72(4), 396-402. https://doi.org/10.1590/brag.2013.050

FAO (Food and Agriculture Organization of the United Nations). (2018). Crops. Retrieved from http://www.fao.org/faostat/en/\#data/QC

Ferreira, D. F. (2011). Sisvar: a computer statistical analysis system. Ciência e Agrotecnologia, 35, 1039-1042. https://doi.org/10.1590/S1413-70542011000600001

Filgueira, F. A. R. (2008). Novo manual de olericultura (3rd ed., p. 421). Viçosa, MG: Editora UFV.

Filho, J. U. P., Freire, M. B. G. dos S., Freira, F. J., Miranda, M. F. A., Pessoa, L. G. M., \& Kamimura, K. M. (2013). Produtividade de alface com doses de esterco de frango, bovino e ovino em cultivos sucessivos. Revista Brasileira de Engenharia Agrícola e Ambiental, 17(4), 419-424. https://doi.org/10.1590/S1415-436 62013000400010

Guimarães, G., Lana, R. de P., Rei, R. de S., Veloso, C. M., Souza, M. R. de M., Rodrigues, R. C., \& Campos, S. A. (2016). Sugarcane production fertilized with poultry litter. Revista Brasileira de Saúde e Produção Animal, 17(4), 617-625. https://doi.org/10.1590/s1519-99402016000400006

Hunter, J. D. (2007). Matplotlib: A 2D Graphics Environment. Computing in Science \& Engineering, 9(3), 90-95. https://doi.org/10.1109/MCSE.2007.55

Lima, P. G., Braga, W. R. O., Lourenzani, A. E. B. S., \& Forti, J. C. (2016). Análise da gestão de resíduos sólidos gerados por galinhas poedeiras em uma granja familiar. Brazilian Journal of Biosystems Engineering, 10(4), 403-415. https://doi.org/10.18011/bioeng2016v10n4p403-415

Lin, Y., Ye, G., Kuzyakov, Y., Liu, D., Fan, J., \& Ding, W. (2019). Long-term manure application increases soil organic matter and aggregation, and alters microbial community structure and keystone taxa. Soil Biology and Biochemistry, 134, 187-196. https://doi.org/10.1016/j.soilbio.2019.03.030 
Medeiros, J. G., Pereira, W., \& Miranda, J. E. C. A. (1990). Análise de crescimento em duas cultivares de batata-doce (Ipomoea batatas (L.) Lam). Revista Brasileira de Fisiologia Vegetal, 2, 23-29.

Minitab, L. L. C. (2019). Introdução ao Minitab 19. Retrieved from http://www.minitab.com

Moreira, J. N., Queiroga, R. C. F., Júnior, A. J. de L. S., \& Santos, M. A. (2011). Caracteres morfofisiológicos e produtivos de cultivares de batata-doce, em Mossoró, RN. Revista Verde, 6(1), 161-167. Retrieved from https://www.gvaa.com.br/revista/index.php/RVADS/article/view/550/533

Natalli, L. H., Munaretto, L. F., Bianchini, D. C., \& Henkes, J. A. (2020). Práticas de sustentabilidade ambiental em propriedades rurais. Revista Gestão e Sustentabilidade Ambiental, 9(1), 351-374. https://doi.org/ 10.19177/rgsa.v9e12020351-374

Oliveira, A. P. de, Barbosa, A. H. D., Cavalcante, L. F., Pereira, W. E., \& Oliveira, A.N.P. de. (2007). Produção da batata-doce adubada com esterco bovino e biofertilizante. Ciência e Agrotecnologia, 31(6), 1722-1728. https://doi.org/10.1590/S1413-70542007000600018

Oliveira, L. O. F. de, Soares, E. R., Queiroz, S. F. de, Martinez, E. O., Silva, M. S. da, Nogueira, A. E., ... Vezzaro, A. de F. G. da S. (2017). Adubação e nutrição da batata-doce: uma revisão. Revista Científica da Faculdade de Educação e Meio Ambiente, 8(2). https://doi.org/10.31072/rcf.v8i2.569

Primavesi, A. (2014). Pergunte ao solo e às raízes: Uma análise do solo tropical e mais de 70 casos resolvidos pela agroecologia (1st ed., p. 272) São Paulo, SP: Nobel.

Queiroga, R. C. F., Santos, M. A., Menezes, M. A., Vieira, C. P. G., \& Silva, M. C. (2007). Fisiologia e produção de cultivares de batata-doce em função da época de colheita. Horticultura Brasileira, 25(3). https://doi.org/10.1590/S0102-05362007000300010

Raij, B. V. (2011). Fertilidade do solo e manejo de nutrientes (p. 420). Piracicaba, SP: IPNI.

Ribeiro, J., Hopkins, M., Vicentini, A., Sothers, C., Costa, M., Brito, J., ... Procopio, L. (1999). Flora da Reserva Ducke: Guia de identificação das plantas vasculares de uma floresta de terra-firme na Amazônia Central (p. 816). Manaus: INPA.

Rós, A. B. (2017). Produtividade e formato de raízes tuberosas de batata-doce em função do número de gemas enterradas. Cientifica, 45(3), 253-256. https://doi.org/10.15361/1984-5529.2017v45n3p253-256

Rós, A. B., Narita, N., \& Hirata, A. C. S. (2014). Produtividade de batata-doce e propriedades físicas e químicas de solo em função de adubação orgânica e mineral. Semina: Ciências Agrárias, 35(1), 205-214. https://doi.org/10.5433/1679-0359.2014v35n1p205

Santos Neto, A. R., Silva, T. O., Blank, A. F., Silva, J. O., \& Araújo Filho, R. N. (2017). Produtividade de clones de batata doce em função de doses de nitrogênio. Horticultura Brasileira, 35(3). https://doi.org/10.1590/ S0102-053620170322

Silva, G. O. da, Suinaga, F. A., Ponijaleki, R., \& Amaro, G. B. (2015). Desempenho de cultivares de batata-doce para caracteres relacionados com o rendimento de raiz. Revista Ceres, 62(4), 379-383. https://doi.org/ 10.1590/0034-737X201562040007

Silva, G. O., Ponijaleki, R., \& Suinaga, F. A. (2012). Divergência genética entre acessos de batata-doce utilizando caracteres fenotípicos de raiz. Horticultura Brasileira, 30, 595-599. https://doi.org/10.1590/ S0102-05362012000400006

Silva, J. B. C. da, Lopes, C. A., \& Magalhães, J. S. (2008). Batata-doce (Ipomoea batatas): Nutrição e Adubação. Embrapa Hortaliças. Retrieved from https://sistemasdeproducao.cnptia.embrapa.br/FontesHTM L/Batata-doce/Batata-doce_Ipomoea_batatas/material_propagacao.html

Silva, J. O. V., Almeida, M. F., Alvim-Ferraz, M. da C., \& Dias, J. M. (2018). Integrated production of biodiesel and bioethanol from sweet potato. Renewable Energy, 124, 114-120. https://doi.org/10.1016/j.renene.2017. 07.052

Strassburg, U., Oliveira, N. M., Piacenti, C. A., \& Piffer, M. (2014). Notas sobre a função de produção agropecuária agregada do Paraná. Revista de Política Agrícola, 13(3), 18-28. Retrieved from https://www.researchgate.net/publication/281819250_Notas_sobre_a_Funcao_de_Producao_Agropecuaria_ Agregada_do_Parana 
Suparno, A., Prabawardani, S., \& Pattikawa, A. (2016). The Nutritional Value of Sweet Potato Tubers [Ipomoea batatas (L.) Lamb.] Consumed by Infants and Children of Dani Tribe in Kurulu District, Baliem-Jayawijaya. Journal of Agricultural Science, 8(3), 64-69. https://doi.org/10.5539/jas.v8n3p64

Varian, H. R. (2000). Microeconomia: Princípios básicos (5th ed., p. 756). Rio de Janeiro, RJ: Campus.

Villordon, A., Solis, J., Labonde, D., \& Clark, C. (2010). Development of a prototype bayesian network model representing the relationship between fresh market yield and some agroclimatic variables known to influence storage root initiation in sweet potato. HortScience, 45, 1167-1177. https://doi.org/10.21273/ HORTSCI.45.8.1167

Vizzotto, M., Pereira, E. dos S., Castro, L. A. S., Raphaelli, C. de O., \& Krolow, A. C. (2017). Composição mineral em genótipos de batata-doce de polpas coloridas e adequação de consumo para grupos de risco. Brazilian Journal of Food Technology, 21. https://doi.org/10.1590/1981-6723.17516

\section{Copyrights}

Copyright for this article is retained by the author(s), with first publication rights granted to the journal.

This is an open-access article distributed under the terms and conditions of the Creative Commons Attribution license (http://creativecommons.org/licenses/by/4.0/). 